\title{
Environmental Communication in Latvian Municipal Newsletters
}

\author{
Ianis Bucholtz \\ Vidzeme University of Applied Sciences. Address: Cēsu iela 4, Valmiera, LV 4200, Latvia.
}

\begin{abstract}
The present study reviews environment-related articles in official newsletters issued by municipalities in Latvia. It evaluates the themes and contents associated with environment in order to evaluate the performance of newsletters as providers of relevant information to the population. Official publications of four Latvian municipalitiesMazsalaca, Jürmala, Krāslava, and Kandava-were analyzed. Common themes included nature and its protection, history of the place, social and cultural events, quality of life and performance of the municipality. A widespread approach of engaging the local population is to hold contests and competitions. However, it is uncertain if the response rate help raising the civic participation level significantly. The official newsletters are willing to publish environment-related public relations materials prepared by other institutions of companies, without exhibiting consistent editorial policy of their own. The implications of the continued publication of these newsletters as competitors to the regional independent newspapers are also discussed.
\end{abstract}

Keywords: municipal newsletters, municipal newspapers, journalism, environmental communication, municipal communication.

\section{INTRODUCTION}

One of the tasks of an administration is to keep the stakeholders informed about the topicalities and policies under its supervision. This principle applies to municipal governance, too. The local population is a key stakeholder, and their awareness about their environment and activities of the municipality is crucial to the accountable and effective implementation of these policies.

A communication channel favored by municipalities in Latvia is official newsletters-a print outlet, which in most cases is being distributed for free straight to the mailboxes of all inhabitants [1]. Recently, such practices of publishing have come under fire in Latvia. Media experts have pointed out that these official newsletters attempt to emulate local newspapers and unfairly compete with them in the media market without fulfilling the role of a journalistic outlet. Rather than independently evaluating the work of the local government, these official newsletters serve as a public relations instrument aimed at presenting the municipal council in a positive light.

A recent initiative to restrict the ability of municipalities to pass their official newsletters for mass media in the sense of the "Law on the press and other mass media" has been struck down by the parliament of Latvia [2]. This means that in the near future the Latvian municipalities will continue the previous endeavors of what has been described as providing self-approved and uncritical view on the current events and workings to their voters [3]. As such, this communication practice invites closer evaluation of the messages the municipalities compose and the approaches they take to pass them down to the local inhabitants.

Since official newsletters are issued by municipalities, it is to be expected that their contents reflect the judgement of the municipality regarding which topics and themes should be covered and how. In this study, I analyze how the municipalities cover the environment in their newsletters. The term "environment" here is understood in a broad sense, which includes nature, cultural and historical heritage, safety, and quality of life. The aim of this paper is to evaluate how the municipalities through the environment-related topics reflect on the topicalities of the populated area and how they present the opportunities to participate in the shaping of the environment to their audience.

Communication about the environment is one of the ways in which municipalities can present themselves as an attractive place to live, work, and rest. However, the challenge these newsletters face is to live up to standards - if not to those of independent media, then at least to those of public relations in the positive sense of the term. Rather than simply influencing the perceptions of the municipality among the population, municipal public relations denote communication between the local government and the citizens "in the interest of an informed public opinion" [4].

Since municipal newsletters compete with the independent outlets in the media market, it is 
important to evaluate the diversity and thoroughness of these newsletters. The absence of such qualities reduces the justification for municipalities to operate in the media business even further.

\section{METHODOLOGY}

Newsletters of four municipalities in LatviaMazsalaca, Krāslava, Kandava, and Jūrmala-were reviewed. The municipalities were selected to reflect the diversity of areas in terms of size of territory and population, availably of natural and cultural resources, and location.

This study examines the most common environment-related themes in the municipal newsletter. Rather than defining relevant codes based on the previous theoretical assumptions, the paper seeks patterns during the review of the data and presents insights based on them. As such, this approach is influenced by the core ideas of the grounded theory [5].

Four municipal newsletters were analyzed. "Jūrmalas pašvaldības informatīvais biḷetens" (The newsletter of Jūrmala municipality), which in 2016 was renamed "Jūrmalas avīze" (Jūrmala newspaper), contains 16 pages is issued twice a month; "Kandavas novada vēstnesis" (Kandava municipality herald) has 16 pages and is issued once a month; "Krāslavas vēstis" (Krāslava tidings) is issued twice a month and contains eight pages; and "Mazsalacas novada zinas" (Mazsalca municipality news) is published once a month and has eight pages.

In the sample, I included the issues from 2015 and 2016.

\section{RESULTS}

A number of common environment-related topics and publishing practices were identified during the examination of articles. Tis subsection provides and overview of them.

\section{Nature and the protection of nature}

Nature is an important resource that can be linked to a number of other aspects that describe the conditions in the particular area and the quality of life.

While the newsletters do touch upon such themes from time to time, articles in this category tend to cover relatively narrow aspects of the protection of nature and are being published as a reaction to specific events or behaviors by the population. Little attention is devoted to raising awareness of the importance of nature or detailing the current state of the issue in the area.

Newsletters readily publish articles on the annual joint work activities "Lielā talka," which take place each spring in Latvia. The aim of "Lielā talka" is to involve other people in tidying up littered territories - this non-governmental initiative was started in 2008 and now has become a steady tradition maintained by local coordinators in many territories in Latvia [6]. The politicians of municipalities also take part in the work, presumably as a publicity stunt, and newsletters report on what has been achieved during the joint work and what the superiors of the municipality did.

Few articles include a call to action for readers regarding other activities related to the protection of the environment. Additionally, newsletters generally lack proactive attempt to discourage undesirable or hazardous human behavior, even in cases when such a behavior is seasonal in nature. An example here is burning of last year's grass in spring - a dangerous and harmful "tradition" of clearing up a territory in which grass has not been cut the year before. Municipal newsletters report that incineration is taking place and that it poses a danger to both nature and property. However, little attention is being paid to this practice before it breaks out - although it is to be expected that at least to some extent the burning will occur each year and thus it is important to inform people about the costs and other disadvantages of this Latvian practice in advance.

All in all, the studied newsletters pay relatively small attention to provision of information about nature, its significance and the need to protect it. Furthermore, little effort is made to address the readers proactively and ask them to do or abstain from doing certain things that harm the nature.

Cultural environment, education, and society

All of the reviewed newsletters cover current events in the territory-news from schools, cultural or sports events; occasionally feature stories and interviews with notable people take up a large part of their pages. Examples of such articles are those that inform about marine-themed exhibitions in Jürmala [7], a storytelling evening on love in Mazsalaca library [8], or the $130^{\text {th }}$ anniversary of Zante primary school in Kandava municipality [9]. This kind of information is arguably relatively easy to obtaincultural events and various school activities usually take place regularly, with or without a direct a participation from the municipality.

Simultaneously such reports are particularly useful for the image-building of the municipality. They construct a general perception about the vibrant social and cultural life of the place, and the readers will get a sense that their place or residence is not an isolated and abandoned territory where nothing happens.

\section{History and the present}

History plays a significant role in shaping the perceptions of an inhabited territory and promoting the identification of the population with it [10]. Knowing how their town, parish, or district has developed through the time, may foster the 
development of the sense of belonging and increase the awareness of the environment.

The reviewed newsletters differ greatly in the way they cover such themes. "Mazsalacas novada zinnas" publishes a column "Mana nama stāsts" (The story of my house), which extensively and in detailed manner describes the history of particular buildings in the municipality. "Kandavas novada vēstnesis" on a regularly provides local historian Agris Dzenis' stories on different places and people related to the municipality.

The other two municipalities take a more passive approach. They may cover commemorations of historic events that take place in the territory, but in many cases, such events simultaneously serve as a photo opportunity for local politicians. For example, in 2015, Krāslava newsletter reported on the commemoration of the liberation of Latgale in 1920 [11]-however, the article seemed to pay more attention to the fact that among the guests of the event were the Latvian minister of Defense and representatives of the Polish embassy than to the analysis of the historical events. While the presence of dignitaries does act as a marker of significance, it is important not to lose focus on other important roles that commemoration, remembrance, and other history-related themes have in societies.

\section{The quality of life and the performance of the municipality}

The concept of environment also relates to the living conditions in the particular municipality. The newsletters typically put great emphasis on the positive contributions the municipality councils provide to the territory, such as various improvements, renovations, innovations, attraction on investment, and the like. Examples of the coverage of such aspects are articles about the successful implementation of the project for the development of water management in Jūrmala [12]; the column of the chairman of the Kandava municipality, in which he explains how the municipality council intends to solve some of the practical problems, such as excessive dust on country roads [13]; or plans to demolish an abandoned and dangerous building in Krāslava [14].

It was to be expected that the leadership of a municipality would attempt to present themselves as attentive to the needs of the population and constantly making things better. In this regard, somewhat more telling are reflections on the current situation in the municipality, including acknowledgement of various deficiencies - or the lack thereof.

The newsletters usually are reluctant to take such an approach, and their role as the mouthpieces of municipal councils prevents them from evaluating critically the work of the municipality. Articles that discuss the living conditions, societal problems, or measure political sentiment among the local population are virtually inexistent. However, sometimes these outlets are able at least mention the problems and challenges the local population face and provide useful information that might help the audience to evaluate the situation in a realistic manner.

A rare example of this is from Krāslava. One of the Latvian towns in which SEB bank recently closed its branch, thus for the time being Krāslava was left without a single bank office in the town. A number inhabitants reportedly had taken the news as an ominous sign-today a bank office is closed, tomorrow other services might follow, including the post office and bus terminal. Krāslavas vēstis reacted to these rumors and attempted to counter them [15].

\section{The involvement of audience}

Apart from the most prominent environmentrelated topics in the newsletters, another theme became apparent - the way these outlets speak to the audience and what efforts they put into encouraging them to take part in shaping of their own environment and contribute to it. Addressing the population can be seen as a recognition - a reciprocal relationship that holds a potential to raise civic engagement [16].

Articles that encourage active participation of the readers in environmental issues instead or merely providing information are quite rare. Such an approach mostly can be observed in articles that cover the issues of nature and ecology-for example, it manifests itself through the calls not to burn the last year's grass [17], an issue discussed previously, or appeals not dispose trash outside the designated places.

However, municipalities do try to involve people, usually through various contests. Among such contests announced in the newsletters were an idea competition for a new environmental object for newly-weds [18], photo contest in which participants are urged to present a place dear to them [19], project tenders for landscaping activities [20], to name a few. Usually it is not clear how popular such competitions are and how many submissions the organizers receive. However, Krāslava municipality reported that it received six submissions to the idea contest for the newly-weds' environmental object [21]. Given that this town has more than 9000 inhabitants and the competition was described in a multiple issues of the newsletter, it is not a large number.

Such contests as a way to invite the civic involvement involve a considerable risk that they are appealing mostly to the part of the population that already is socially engaged - and this segment might be a minority. To reach out to a wider public, the municipalities should provide more diverse opportunities of participation, which does not necessarily involve submission of competition materials to the municipality. 


\section{Authors of the publications}

Typically, the articles published in the municipal newsletters are written by authors who work for the municipality. However, a number of environmentrelated articles come from external sources. Publications on the protection of nature in many cases have been based on press releases from, for example, the waste management company "ZAAO," which urges people to sort waste for recycling or describes the achievements of the company [22]; the Latvian Ministry of Agriculture, which informed about the hunting of wild animals that cause damage to farms and forests [23]; or used paper collection competition held by the waste management society "Piejūra" [24].

Newsletters also publish externally prepared public relations materials on other topics, such as cultural events [25], but the difference is that press releases written by commercial companies or governmental institutions usually are not uniquely targeted at the audience of the particular newsletter. These are published in newsletters of other municipalities and unrelated media outlets, too.

Such a practice illustrates a pattern of utilizing information submitted by other organizations and companies, rather than formulating and executing the newsletter's agenda based on its own editorial principles. Thus, instead of reflecting the conscious attention the municipality might want to pay towards environmental issues, such articles frequently are the result of public relations and publicity efforts by other parties. Such an approach leaves segments of environmental communication to drift on its own, instead of being directed by the environmental policy of the municipality.

\section{CONCLUSIONS}

The newsletters of four municipalitiesMazsalaca, Kandava, Krāslava, and Jūrmala-do cover numerous environment-related topics. At the same time, these media outlets generally leave much to be desired in terms of their ability or willingness to address the urgent issues that the local population faces in their diversity. The fact that these newsletters cover activities of the very same institutions that are responsible for these outlets means that only issues and interpretations favorable towards the municipality are printed.

Municipal newsletters provide information about the natural, historical, cultural, and social environment of the inhabited place, but the publications do not suggest the existence of consistent editorial policies that underlie their selection and execution of themes. Articles on the protection of nature are published sporadically and usually retroactively. Many other environmentrelated themes gain prominence mostly in case if something good has happened or is about to happen-water management system reconstructed, dangerous building torn down, dust on roads reduced.
Shortcomings or deficiencies usually are only acknowledged if the municipality simultaneously is not able to promise solutions to them. The newspapers are willing to present successes in various fields of municipal activities, but the few articles discuss challenges the municipality faces are more of exception.

A stable thematic direction is cultural and social life, though, and some newsletters also pay considerable attention to history. Nonetheless, history, as well as the depiction of social and cultural events is themes through which municipal newsletters can emulate independent regional newspapers the closest. These topics are also covered by these newspapers, which traditionally have played an important role in shaping the local cultural identity, while at the same time being part of it [26]. Thus, municipal newsletters also claim a role in shaping local identity, albeit in a more restricted way.

The inconsistency of editorial policy toward environment-related topics is also evident in the authorship of the articles. Usually publications are written by the newsletter staff and/or public relations people of the municipality. However, it is not uncommon, especially regarding topics related to the natural protection and safety from various hazards, that these newsletters publish materials prepared by other institutions or companies. Such a practice creates an impression that the newsletter is very open to outside contributions that allow them to fill the space of the paper with relatively little effort.

Thus, the findings once again bring into focus the function of municipal newsletters as public relations instruments, rather than real journalistic media, which are bound by such principles as impartiality, editorial autonomy, immediacy, and providing public service to the society [27]. The distinction between independent local newspapers and municipal newsletters admittedly is not always clear-cut: the newsletters do also publish valuable and timely content, and some of the articles referred to in this paper illustrate this. It is also possible that a nominally independent media outlet reports on the activities of a municipality in an uncritical manner [28]. However, readers of municipal newsletters should be aware of the limitations this media genre has so that they do not confuse an imitation of a journalistic outlet with a genuine one.

Since the Latvian parliament has rejected the recent proposals to restrict the rules of publication for these newsletters [2], it is to be expected that the current practice will continue in the future. Under such conditions, one can only - naïvely - hope that the municipal leaders in Latvia themselves are capable of redefining the purpose of their official outlets from that of publicity instrument to providing the population with more relevant and wellconsidered information on their natural, cultural, and living environment. 


\section{V.ACKNOWLEDGMENTS}

This study was supported by the National Research Program "Economic transformation, smart growth, governance, and legal framework for the state and society for sustainable development - a new approach to the creation of a sustainable learning community (Ekosoc_lv)", project Nr. 2.5.8 "The processes of the development of cultural environment, preservation of environmental diversity and urbanization in the context of balanced development of Latvia."

\section{REFERENCES}

[1] Petrova, A. (2016). State gets to work on municipal newspapers. Public broadcasting of Latvia. 13.10.2016. http://www.lsm.lv/en/article/societ/society/state-gets-towork-on-municipal-newspapers.a205271/

[2] BNS/The Baltic Times. Saeima rejects proposal to ban municipalities from funding mass media. The Baltic Times. 2017.02.02.

http://www.baltictimes.com/saeima rejects proposal to ban _municipalities_from_funding_mass_media/

[3] Ândersone, I. Latvia: Discussions about municipal newsletters and media independence. European Centre for press and media freedom. 2016. https://ecpmf.eu/news/legal/archive/latvia-discussions-aboutmunicipal-newsletters-and-media-independence

[4] Wheeler, P. D. Municipal public relations. The American Journal of Economics and Sociology, 15(3), 1956. pp. 315320.

[5] Glaser, B. G., Strauss, A. L. The discovery of grounded theory: Strategies for qualitative research. New Brunswick: Aldine Transaction, 2006.

[6] Talkas.lv. Talkas ideja. http://www.talkas.lv/?page=558

[7] Jūrmalas pašvaldības Sabiedrisko attiecību nodalia. Vairāk jūras tematikai veltītu izstāžu. Jūrmalas avīze. 2016.07.07. http://news.lv/Jurmalas-Avize/2016/07/07

[8] Apsīte, L. (2016). Mīlestības stāsti bibliotēkā. Mazsalacas novada ziṇas, 2. 2016. 2. lpp.

[9] Kandavas novada vēstnesis. Zantes skolai - 130. Kandavas novada vēstnesis, 126(10). 2015, 1. lpp.

[10] Friedman, J. The past in the future: history and the politics of identity. American Anthropologist, 94(4). 1992, pp. 837-859.
[11] Škutāne, E. Pasākums par godu kritušajiem poḷu karavīriem. Krāslavas vēstis, 1. 2015, 4. lpp

[12] Zaķe, A. Sekmīgi īstenota Jūrmalas ūdenssaimniecības attīstības projekta trešā kārta, Jūrmalas avīze, 2016.07.07.

[13] Štoferts, N. Novada svētki. Kandavas novada vēstnesis, 134(6). 2016, 2. lpp.

[14] Krāslavas vēstis. Bijušās viesnīcas ēka tiks demontēta. Krāslavas vēstis, 276(11). 2016, 4. lpp.

[15] Škutāne, E. "Dariet, ko spējat, ar to, kas jums ir, tieši tur, kur esat!’ Krāslavas vēstis, 2. 2015, 4. lpp.

[16] Divay, G., \& Micheau, M. Recognizing citizens in municipal management: An exploratory study based on a content analysis of municipal websites in the province of Quebec. International Review of Administrative Sciences. 2016.

[17] Cepurīte, E. Sausās zāles dedzināšana ir bīstama cilvēkam un kaitē videi. Jūrmalas pašvaldības informatīvais biḷetens, 83(48). 2015.

[18] Krāslavas vēstis. Jauns vides objekts kāziniekiem Krāslavas pils kompleksā. Krāslavas vēstis, 3. 2015, 4. lpp.

[19] Kandavas novada vēstnesis. Piedalies fotokonkursā „Ar mīlestību savā novadā”. Kandavas novada vēstnesis, 118(2). 2015, 10-11. lpp.

[20] Jūrmalas pilsētas dome. Iedz̄ivotāju iniciatīvas projekti. Jurmala.lv. 2015. http://www.jurmala.lv/page/1851

[21] Kozačuka, T. Tuvākajā laikā pils kompleksu rotās skaista "Mīlas kariete". Krāslavas vēstis, 252(7). 2015, 4. lpp.

[22] Leimane, Z. Dzīvot ietaupot un videi draudzīgi. Mazsalacas novada vēstis, 12. 2016, 2. lpp.

[23] Kalniņa, V. Par savvaḷas medījamo dzīvnieku postījumiem. Krāslavas vēstis, 13. 2016, 2. lpp.

[24] Atkritumu apsaimniekošanas sabiedrība "Piejūra". Aicina piedalīties makulatūras vākšanas konkursā. Kandavas novada vēstnesis, 10. 2016. 12. lpp.

[25] Krogzeme-Mosgorda, B. \& Pokratniece, K. Latviešu folkloras krātuves izbraukuma seminārs, Mazsalacas novada vēstis, 4. 2016, 2. lpp.

[26] Zelče, V. (2006). Lokālā prese - kopienas informācijas vides veidotāja. Grām.: I. Brikše, Informācijas vide Latvijā: 21. gs. sākums. Rīga: Zinātne, 2006. 144-166. lpp.

[27] Kovach, B. \& Rosenstiel, T. The elements of journalism. New York: Crown Publishers, 2001

[28] Kupčs, E. (2015). Pašvaldību "avīzes" - domju slavināšana un izklaides raksti, zaudēta demokrātija nākotnē. Latvijas sabiedriskie mediji. 2015.11.30. http://www.lsm.lv/lv/raksts/zinju-analiize/zinas/pasvaldibuavizes--domju-slavinasana-un-izklaides-raksti-zaudetademokratija-nakotne.a157269/ 